\title{
Alkalibacterium iburiense sp. nov., an obligate alkaliphile that reduces an indigo dye
}

Correspondence Isao Yumoto i.yumoto@aist.go.jp

\author{
Kenji Nakajima, ${ }^{1}$ Kikue Hirota, ${ }^{1}$ Yoshinobu Nodasaka ${ }^{2}$ and Isao Yumoto ${ }^{1,3}$ \\ ${ }^{1}$ Research Institute of Genome-based Biofactory, National Institute of Advanced Industrial \\ Science and Technology (AIST), Tsukisamu-Higashi, Toyohira-ku, Sapporo 062-8517, Japan \\ ${ }^{2}$ Laboratory of Electron Microscopy, Graduate School of Dentistry, Hokkaido University, Kita-ku, \\ Sapporo 060-8586, Japan \\ ${ }^{3}$ Graduate School of Agriculture, Hokkaido University, Kita-ku, Sapporo 060-8589, Japan
}

\begin{abstract}
Three indigo-reducing obligately alkaliphilic strains, $M 3^{\top}, 41 \mathrm{~A}$ and $41 \mathrm{C}$, were isolated. The isolates grew at $\mathrm{pH} 9-12$, but not at $\mathrm{pH} 7-8$. They were Gram-positive, facultatively anaerobic, straight rod-shaped strains with peritrichous flagella. The isolates grew in $0-14 \%(\mathrm{w} / \mathrm{v}) \mathrm{NaCl}$, with optimum growth at 3-13\%. They grew at temperatures between 10 and $45{ }^{\circ} \mathrm{C}$, with optimum growth at around $30-37^{\circ} \mathrm{C}$. They did not hydrolyse starch or gelatin. DL-Lactate was the major end-product from D-glucose. No quinones could be detected. The peptidoglycan type was $A 4 \beta$, Orn-D-Asp. The major cellular fatty acids were $\mathrm{C}_{16: 0}, \mathrm{C}_{16: 1} 7 c$ and $\mathrm{C}_{18: 1} 9 c$. The DNA G $+C$ content was 42.6-43.2 mol\%. Phylogenetic analysis based on 16S rRNA gene sequence data indicated that the isolates belong to the genus Alkalibacterium. DNA-DNA hybridization revealed low similarity (less than $16 \%$ ) of the isolates with respect to the two closest phylogenetically related strains, Alkalibacterium olivapovliticus and Alkalibacterium psychrotolerans. On the basis of phenotypic and chemotaxonomic characteristics, phylogenetic data and DNA-DNA relatedness, the isolates merit classification as a novel species of the genus Alkalibacterium, for which the name Alkalibacterium iburiense is proposed. The type strain is $\mathrm{M3}^{\top}\left(=\mathrm{JCM} 12662^{\top}=\mathrm{NCIMB} 14024^{\top}\right)$.
\end{abstract}

Alkaliphilic bacteria have been isolated in order to investigate their diversity in terms of environments, taxonomy, physiological adaptation to high $\mathrm{pH}$ and the industrial application of their enzymes (Horikoshi, 1991; Duckworth et al., 1996; Takami et al., 1997; Krulwich \& Guffanti, 1989; Krulwich et al., 2001; Yumoto, 2002, 2003; Thongaram et al., 2003). Most of the strains used for investigation and industrial utilization belong to the genus Bacillus. Such alkaliphilic bacteria have been isolated mostly from soil samples and other environments, e.g. fermentation process and water environments. Alkaliphilic bacteria are distributed not only in soil but also in sea water, fresh water, the intestines of insects, alkaline soda lakes and deep-sea and artificial environments (Nielsen et al., 1995; Duckworth et al., 1996; Takami et al., 1997; Thongaram et al., 2003;

Published online ahead of print on 17 February 2005 as DOI 10.1099/ ijs.0.63487-0.

The GenBank/EMBL/DDBJ accession numbers for the 16S rRNA gene sequences of strains $M 3^{\top}, 41 \mathrm{~A}$ and $41 \mathrm{C}$ are $\mathrm{AB} 188091$, $\mathrm{AB} 188092$ and $\mathrm{AB} 188093$, respectively.

A transmission electron micrograph showing the peritrichous flagellation of strain $\mathrm{M}^{\top}$ is available as a supplementary figure in IJSEM Online, along with a supplementary table showing DNA-DNA relatedness among the strains examined in this study.
Ntougias \& Russell, 2001; Yumoto et al., 2004). In artificial environments, alkaliphilic bacteria belonging to genera other than Bacillus also exist.

The traditional method for producing indigo blue dye had been based on fermentation by alkaliphilic bacteria existing in ubiquitous environments in Japan. The harvested indigo leaves are air-dried and then appropriately wetted before being further processed using moisture-controlled bacterial oxidation. The product obtained is further processed by microbial reduction under alkaline conditions $(\mathrm{pH}$ values above 10), at which point the original insoluble oxidized form of indigo is converted to a soluble reduced form. The fermentation method for producing indigo dye by using alkaliphilic bacteria had declined by around 1960 because of the difficulty in managing the fermentation process. Then, a chemical reducing reagent was introduced to replace the bacterial reduction. If we can understand the characteristics of these bacteria in relation to fermentation, it might be easier to manage the fermentation process. A return to the traditional method might diminish the use of the chemical reagent. Indigo-reducing bacteria have been isolated by Takahara \& Tanabe (1960) and Padden et al. (1999) and have been identified as a Bacillus species and Clostridium isatidis, respectively. In addition to strains $\mathrm{M} 3^{\mathrm{T}}, 41 \mathrm{~A}$ and 
41C, we have also isolated Alkalibacterium psychrotolerans, which is an indigo-reducing bacterium that has recently been described taxonomically (Yumoto et al., 2004).

In this study, halotolerant, psychrotolerant, obligately alkaliphilic strains that can reduce indigo at high $\mathrm{pH}$ values were isolated and characterized. Phenotypic and chemotaxonomic characteristics, phylogenetic analysis based on 16S rRNA gene sequences and DNA-DNA hybridization showed that the isolates merit classification as a novel species of the genus Alkalibacterium.

Fermented polygonum indigo (Polygonum tinctorium Lour.) samples were obtained from Date city $\left(42^{\circ} 42^{\prime} \mathrm{N}\right.$, $140^{\circ} 42^{\prime}$ E), Hokkaido, Japan, on 5 July 2002. At the same time, $5 \mathrm{ml}$ of the fermentation liquor was inoculated into $100 \mathrm{ml} \mathrm{0.01 \%} \mathrm{indigo-containing} \mathrm{PYA} \mathrm{(peptone/yeast}$ extract/alkaline) broth consisting of $8 \mathrm{~g}$ peptone (Kyokuto), 3 g yeast extract (Merck), $1 \mathrm{~g} \mathrm{~K}_{2} \mathrm{HPO}_{4}, 3 \cdot 5 \mathrm{mg}$ EDTA, $3 \mathrm{mg}$ $\mathrm{ZnSO}_{4} .7 \mathrm{H}_{2} \mathrm{O}, 10 \mathrm{mg} \mathrm{FeSO}_{4} \cdot 7 \mathrm{H}_{2} \mathrm{O}, 2 \mathrm{mg} \mathrm{MnSO}_{4} .5 \mathrm{H}_{2} \mathrm{O}$, $1 \mathrm{mg} \mathrm{CuSO}_{4} \cdot 5 \mathrm{H}_{2} \mathrm{O}, 2 \mathrm{mg} \mathrm{Co}\left(\mathrm{NO}_{3}\right)_{2} \cdot 6 \mathrm{H}_{2} \mathrm{O}$ and $1 \mathrm{mg}$ $\mathrm{H}_{3} \mathrm{BO}_{3}$ in $1 \mathrm{l} \mathrm{NaHCO}_{3} / \mathrm{Na}_{2} \mathrm{CO}_{3}$ buffer $(100 \mathrm{mM}$ in deionized water; $\mathrm{pH} 10$ ) at $27^{\circ} \mathrm{C}$. After checking for microbial reduction, the culture was transferred to another $100 \mathrm{ml}$ fresh $0.01 \%$ indigo-containing PYA broth. This enrichment process was performed five times using the same medium. During the screening process involving about 40 isolates and our laboratory strains, one alkaliphilic laboratory strain was contaminated with a micro-organism that also tested positive for indigo reduction. This fraction was also processed by using the enrichment process described above. The enrichment culture thus obtained was inoculated onto a reinforced clostridial agar (RCA; Sigma) plate containing $100 \mathrm{mM} \mathrm{NaHCO} / \mathrm{Na}_{2} \mathrm{CO}_{3}$ buffer at $\mathrm{pH} 10$ (alkali-RCA) and incubated in an argon exchange jar. Although one strain $\left(\mathrm{M}^{\mathrm{T}}\right)$ was isolated independently from contaminated culture in our laboratory, two strains (41A and 41C) were isolated as colonies with different features from the same sample and using the same isolation process. After $48 \mathrm{~h}$ cultivation, single colonies were picked and reisolated five times using alkali-RCA plates. The purified colonies obtained were inoculated into $0.01 \%$ indigo-containing PYA broth to check the ability of the isolate to reduce indigo. Cells for chemotaxonomic analysis were harvested in the late-exponential phase after cultivation with reciprocal shaking ( 130 r.p.m. $\left.\min ^{-1}\right)$ at $27^{\circ} \mathrm{C}$ in reinforced clostridial broth (RCB; Sigma) containing $100 \mathrm{mM} \mathrm{NaHCO} / \mathrm{Na}_{2} \mathrm{CO}_{3}$ buffer at pH 10 (alkali-RCB). Alkali solution for media used in this study was sterilized separately by autoclaving.

For phenotypic characterization, alkali-RCA or alkali-RCB was used as the basal medium. The culture was incubated at $27^{\circ} \mathrm{C}$ for 2 weeks and experiments were performed three times to confirm the reproducibility of results. Acid production from carbohydrates was determined by the method of Hugh \& Leifson (1953), using thymol blue $(0.008 \%, w / v)$ instead of bromothymol blue at $\mathrm{pH} 10$. Growth experiments at $\mathrm{pH} 7-10$ were performed using PYA medium containing $100 \mathrm{mM} \mathrm{NaH} \mathrm{PO}_{4} / \mathrm{Na}_{2} \mathrm{HPO}_{4}$ buffer (pH 7-8), $100 \mathrm{mM} \mathrm{NaHCO} / \mathrm{Na}_{2} \mathrm{CO}_{3}$ buffer (pH 9-10) or $100 \mathrm{mM} \mathrm{Na} \mathrm{CO}_{3} / \mathrm{NaOH}$ buffer $(\mathrm{pH} 11-12 \cdot 3)$. Anaerobic growth was tested in PYA broth $(\mathrm{pH} \mathrm{10)}$ by substituting air with argon gas. Other physiological and biochemical characteristics were examined according to the methods of Yumoto et al. (1998). Antibiotic sensitivity was investigated by placing a paper disc, impregnated with a small amount of antibiotic, on a plate of alkali-RCA medium. For the observation of negatively stained cells by transmission electron microscopy (model H-800 microscope; Hitachi), cells were grown on alkali-RCA; preparation and observation were performed as described previously (Yumoto et al., 2001). The morphological, physiological and biochemical characteristics of the isolate are given in the species description. The isolates grew almost equally well at $\mathrm{pH}$ values 9-12, but not at $\mathrm{pH} 7-8$, the optimum $\mathrm{pH}$ being $9 \cdot 5-10 \cdot 5$. They were facultatively anaerobic. Three strains were isolated using alkali-RCA ( $\mathrm{pH} 10)$. Colonies of strains $\mathrm{M}^{\mathrm{T}}, 41 \mathrm{~A}$ and $41 \mathrm{C}$ on an alkali-RCA plate were circular, convex and pale white; the cells of the isolates were Gram-positive, peritrichously flagellated rods measuring $0 \cdot 5-0 \cdot 7 \times 1 \cdot 3-2 \cdot 7 \mu \mathrm{m}$ and did not produce spores (see the supplementary figure in IJSEM Online). The growth rates of the isolates at $\mathrm{pH} 10$ in aerobic conditions in the temperature range $10-40{ }^{\circ} \mathrm{C}$ were determined using a temperature-gradient incubator (type TN-2612 BioPhotorecorder; Advantec) by monitoring the $\mathrm{OD}_{650}$ value. They grew at temperatures between 10 and $45^{\circ} \mathrm{C}$, their optimum growth temperatures being in the range $30-37^{\circ} \mathrm{C}$. The maximum specific growth rates, $\mu_{\max }\left(\mathrm{h}^{-1}\right)$, for strain M3 ${ }^{\mathrm{T}}$ were as follows: 0.03 at $15^{\circ} \mathrm{C}, 0.15$ at $25^{\circ} \mathrm{C}, 0 \cdot 18$ at $31^{\circ} \mathrm{C}, 0.26$ at $34^{\circ} \mathrm{C}, 0.29$ at $37^{\circ} \mathrm{C}$ and 0.28 at $40^{\circ} \mathrm{C}$. For strain $41 \mathrm{~A}$, the rates were as follows: 0.03 at $15^{\circ} \mathrm{C}, 0 \cdot 11$ at $24^{\circ} \mathrm{C}, 0.13$ at $30^{\circ} \mathrm{C}, 0.09$ at $34^{\circ} \mathrm{C}, 0.09$ at $37^{\circ} \mathrm{C}$ and 0.08 at $40{ }^{\circ} \mathrm{C}$. For strain $41 \mathrm{C}$, the rates were as follows: 0.03 at $15^{\circ} \mathrm{C}$, 0.07 at $24^{\circ} \mathrm{C}, 0.17$ at $30^{\circ} \mathrm{C}, 0.13$ at $34^{\circ} \mathrm{C}, 0.13$ at $37^{\circ} \mathrm{C}$ and 0.07 at $40{ }^{\circ} \mathrm{C}$.

Analyses of whole-cell fatty acids and isoprenoid quinones were performed as described previously (Yumoto et al., 2002). Peptidoglycan and its hydrolysate were prepared by the method of Okada et al. (1992). The amino acid composition was determined using a Hitachi L-8500A automated amino acid analyser. GLC analysis revealed that the cellular fatty acid compositions of strains $\mathrm{M}^{\mathrm{T}}, 41 \mathrm{~A}$ and $41 \mathrm{C}$ are as follows (results for the type strain are shown, with the range for the strain in parentheses): $\mathrm{C}_{10: 0}$, $20 \%(1 \cdot 5-2 \cdot 3 \%) ; \mathrm{C}_{14: 0}, 3 \cdot 2 \%(3 \cdot 2-5 \cdot 3 \%) ; \mathrm{C}_{14: 1} 5 c, 3 \cdot 0 \%$ $(2 \cdot 0-3 \cdot 3 \%) ; \mathrm{C}_{14: 1} 7 c, 1 \cdot 2 \%(0 \cdot 9-1 \cdot 3 \%) ; \mathrm{C}_{16: 0}, 15 \cdot 2 \%$ $(15 \cdot 0-26 \cdot 5 \%) ; \mathrm{C}_{16: 1} 5 c, 4 \cdot 0 \%(3 \cdot 1-4 \cdot 0 \%) ; \mathrm{C}_{16: 1} 7 c, 31 \cdot 1 \%$ $(22 \cdot 8-31 \cdot 1 \%) ; \mathrm{C}_{16: 1} 9 c, 1 \cdot 4 \%(1 \cdot 0-1 \cdot 4 \%) ; \mathrm{C}_{18: 0}, 3 \cdot 1 \%$ $(3 \cdot 1-5 \cdot 9 \%) ; \mathrm{C}_{18: 1} 9 t, 2 \cdot 2 \%(2 \cdot 1-2 \cdot 4 \%) ; \mathrm{C}_{18: 1} 9 c, 31 \cdot 1 \%$ $(24 \cdot 9-31 \cdot 1 \%)$; and $\mathrm{C}_{20: 0}, 2 \cdot 5 \%(2 \cdot 5-3 \cdot 8 \%)$. The isolate contained a large amount of unsaturated fatty acids. The fatty acid compositions of these three isolates were similar to that of Alkalibacterium olivapovliticus rather than that of Alkalibacterium psychrotolerans and Marinilactibacillus 
psychrotolerans. However, the $\mathrm{C}_{16: 0}$ and $\mathrm{C}_{18: 1}$ contents of our isolates were lower and higher than those of A. olivapovliticus, respectively. Of all the Alkalibacterium species, including our isolates, only A. psychrotolerans contained more $\mathrm{C}_{16: 1} 9 c$ than $\mathrm{C}_{16: 1} 7 c$. This means that differences in the lipid biosynthetic pathway may exist in this genus. Isoprenoid quinones could not be detected by HPLC analysis of the concentrated extracted fraction. The purified peptidoglycans of strains $\mathrm{M}^{\mathrm{T}}, 41 \mathrm{~A}$ and $41 \mathrm{C}$ contained aspartic acid, ornithine, glutamic acid and alanine, at a molar ratio of $0 \cdot 6: 1 \cdot 08: 1: 2 \cdot 03$. These results suggested that the strains possess peptidoglycan type A $4 \beta$, Orn-D-Asp. The peptidoglycan amino acid composition is similar to that of A. olivapovliticus NCIMB $13710^{\mathrm{T}}$ but is not similar to that of A. psychrotolerans JCM $12281^{\mathrm{T}}$ or M. psychrotolerans NCIMB $13873^{\mathrm{T}}$.

Fermentation products from D-glucose were analysed by HPLC with a TSKgel Oapak column $(7 \cdot 8 \mathrm{~mm} \times 30 \mathrm{~cm} \times$ 2 columns) (Tosoh). The optical purity of L-lactate in the spent medium was determined by HPLC with a TSKgel ENANRIO L1 column $(4 \cdot 6 \mathrm{~mm} \times 25 \mathrm{~cm}$; Tosoh). The fermentation products of D-glucose $(0.5 \%$ in the medium) utilization were determined. Lactate was produced with a yield of $0 \cdot 68-0 \cdot 82\left[\mathrm{~mol}(\mathrm{~mol} \text { glucose })^{-1}\right]$ of lactate, $1 \cdot 25-1 \cdot 39\left[\mathrm{~mol}(\mathrm{~mol} \text { glucose })^{-1}\right]$ of formate and $0 \cdot 39-0.71$ [mol (mol glucose $\left.)^{-1}\right]$ of acetate. The optical purity of the L-lactate was found to be $46 \%$, indicating that the isolates produced DL-lactate.

Bacterial DNA was prepared according to the method of Marmur (1961). The DNA G +C content was determined by the method of Tamaoka \& Komagata (1984): the values for strains $\mathrm{M}^{\mathrm{T}}, 41 \mathrm{~A}$ and $41 \mathrm{C}$ were in the range $42 \cdot 6-$ $43.2 \mathrm{~mol} \%$ - higher than those of the phylogenetically related species A. olivapovliticus $(39.7 \mathrm{~mol} \%)$ and $A$. psychrotolerans $(40.6 \mathrm{~mol} \%)$.

The 16S rRNA gene was amplified using the PCR method with primers A (5'-GGAGAGTTAGATCTTGGCTCAG-3') and 1541R ( $5^{\prime}$-AAGGAGGTGATCCAGCC-3') for strain $\mathrm{M}^{\mathrm{T}}$, and primers 20F (5'-AGTTTGATCATGGCTCA- $\left.3^{\prime}\right)$ and $1541 \mathrm{R}$ for strains $41 \mathrm{~A}$ and $41 \mathrm{C}$, respectively. Although we do not know the reason for this, we were able to amplify objective DNA of $\mathrm{M}^{\mathrm{T}}$ using primer A but not when using primer $20 \mathrm{~F}$. The PCR product of approximately $1.5 \mathrm{~kb}$ was sequenced directly by the dideoxynucleotide chain-termination method using a DNA sequencer (ABI PRISM 3100; Applied Biosystems/Hitachi) with a BigDye Termination RR mix, version 3.1 (Applied Biosystems) according to the manufacturer's instructions. Multiple alignments of the sequences were performed and the nucleotide substitution rate $\left(K_{\text {nuc }}\right.$ value) was calculated. A phylogenetic tree was constructed by the neighbour-joining method (Kimura, 1980; Saitou \& Nei, 1987), using the CLUSTAL W program (Thompson et al., 1994). Similarity values for sequences were calculated using the GENETYX computer program (Software Development). The 16S rRNA gene sequences of strains $\mathrm{M}^{\mathrm{T}}, 41 \mathrm{~A}$ and $41 \mathrm{C}$ were analysed to determine their phylogenetic positions. The 16S rRNA gene sequences of the three isolates were compared with those of strains belonging to other phylogenetically related taxa. The phylogenetic tree constructed (Fig. 1) and the 16S rRNA gene sequence similarities with 13 related strains (data not shown) showed that the isolates constituted a subcluster with A. olivapovliticus and A. psychrotolerans with high bootstrap values and showed high similarities with Alkalibacterium spp. The similarity values among the three isolates were $99 \cdot 4-99 \cdot 7 \%$, while the values with respect to the related taxa were less than $97 \%$. The three strains were placed in phylogenetic positions related to A. olivapovliticus (Ntougias \& Russell, 2001), A. psychrotolerans (Yumoto et al., 2004) and $M$. psychrotolerans (Ishikawa et al., 2003), all of which are alkaliphiles. The $16 \mathrm{~S}$ rRNA gene sequence of strain $\mathrm{M} 3^{\mathrm{T}}$ was found to have the highest similarities with those of the obligate alkaliphiles A. olivapovliticus $(96 \cdot 2 \%)$ and A. psychrotolerans $(95 \cdot 8 \%)$, the facultative alkaliphile M. psychrotolerans $(95 \cdot 1 \%)$ and the piezotolerant bacterium Marinilactibacillus piezotolerans $(96 \cdot 0 \%)$. Strain $\mathrm{M}^{\mathrm{T}}$ was closer phylogenetically to obligate alkaliphiles (genus Alkalibacterium) than to facultative alkaliphiles (genus Marinilactibacillus). These results demonstrate the obligately alkaliphilic nature of $\mathrm{M}^{\mathrm{T}}$, which is consistent with the phylogenetic placement of this isolate.

According to the results of $16 \mathrm{~S}$ rRNA gene sequence analysis, $\mathrm{M}^{\mathrm{T}}$ is closely related to A. olivapovliticus NCIMB $13710^{\mathrm{T}}$, A. psychrotolerans JCM $12281^{\mathrm{T}}$ and M. psychrotolerans $\mathrm{NCIMB} 13873^{\mathrm{T}}$. A. olivapovliticus $\mathrm{NCIMB} 13710^{\mathrm{T}}$, A. psychrotolerans JCM $12281^{\mathrm{T}}$ and M. psychrotolerans NCIMB $13873^{\mathrm{T}}$ were used as reference strains for DNADNA hybridization. These micro-organisms were cultivated using alkali-RCB by the same method. The level of DNADNA relatedness was determined fluorometrically by the method of Ezaki et al. (1989), using photobiotin-labelled DNA probes and black microplates (F16 Black Maxisorp; Nage Nunc International). Photobiotin-labelled DNA was prepared using photoprobebiotin (SP-1000; Vector Laboratories). DNA-DNA hybridization indicated that strains $\mathrm{M}^{\mathrm{T}}, 41 \mathrm{~A}$ and $41 \mathrm{C}$ belong to the same species $\left(81 \cdot 1-100 \%\right.$ DNA-DNA similarity) and that strain $\mathrm{M}^{\mathrm{T}}$ differs from A. psychrotolerans JCM $12281^{\mathrm{T}}$ (14.1\% DNADNA similarity), A. olivapovliticus NCIMB $13710^{\mathrm{T}}$ (7.3\% DNA-DNA similarity) and $M$. psychrotolerans NCIMB $13873^{\mathrm{T}}$ (3.9\% DNA-DNA similarity) when DNA from strain $\mathrm{M} 3^{\mathrm{T}}$ is used as a probe. Strains $\mathrm{M} 3^{\mathrm{T}}, 41 \mathrm{~A}$ and $41 \mathrm{C}$ are also different from A. psychrotolerans JCM $12281^{\mathrm{T}}$ (10.6-15.1\% DNA-DNA similarity) when DNA from A. psychrotolerans JCM $12281^{\mathrm{T}}$ is used as a probe (see the supplementary table in IJSEM Online). On the basis of DNA-DNA hybridization, 16S rRNA gene sequence similarity and phenotypic and chemotaxonomic characteristics, we conclude that the three isolates belong to the same species.

Strains $\mathrm{M} 3^{\mathrm{T}}, 41 \mathrm{~A}$ and $41 \mathrm{C}$ differed phenotypically and chemotaxonomically from the phylogenetically closely related species A. olivapovliticus, A. psychrotolerans and 


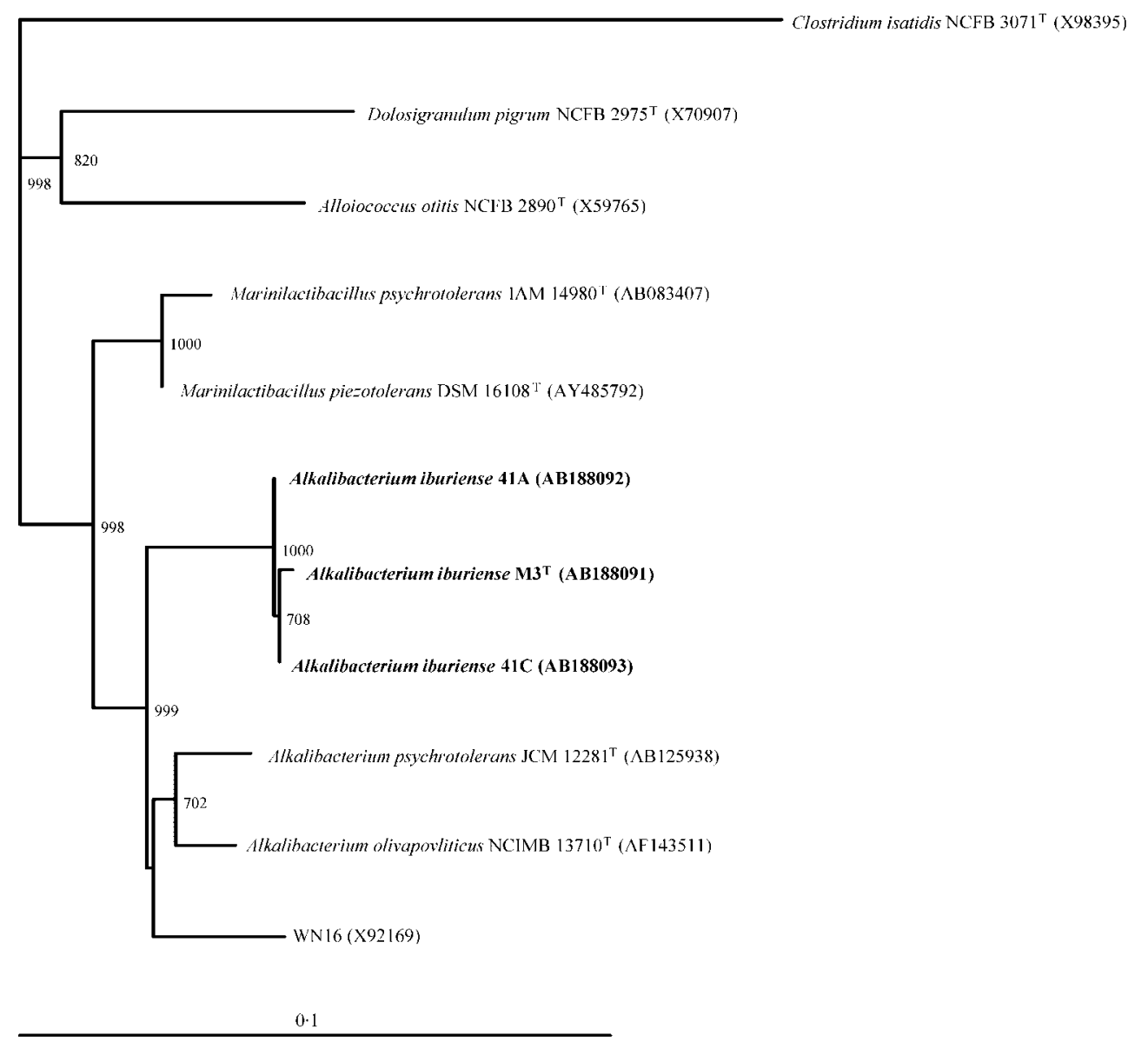

Fig. 1. Phylogenetic tree of Alkalibacterium iburiense strains $M 3^{\top}, 41 \mathrm{~A}$ and $41 \mathrm{C}$ and other related organisms, derived from 16S rRNA gene sequence data by using the neighbour-joining method. Bootstrap values greater than 500 are shown. Bar, $0 \cdot 1 K_{\text {nuc }}$.

M. psychrotolerans, as shown in Table 1. The growth characteristics of the isolates were different from those of A. psychrotolerans (Yumoto et al., 2004) and M. psychrotolerans (Ishikawa et al., 2003). Although the isolates exhibited phenotypic characteristics similar to those of A. olivapovliticus, there were obvious differences in terms of antibiotic sensitivities (chloramphenicol, kanamycin and trimethoprim). The strains belonging to the genus Alkalibacterium could be distinguished from other strains belonging to other phylogenetically related genera. They were distinguishable from strains of the genus Alloiococcus (Aguirre \& Collins, 1992) by catalase reaction, cellular morphology, motility, oxygen requirements, glucose metabolism, growth at $\mathrm{pH} 7$ and DNA G + C content: the genus Alloiococcus comprises catalase-positive, non-motile cocci, is aerobic and does not ferment D-glucose, grows at $\mathrm{pH} 7$ and has a DNA G $+\mathrm{C}$ content of $44-45 \mathrm{~mol} \%$. The strains belonging to the genus Alkalibacterium could be distinguished from those of the genus Dolosigranulum (Aguirre et al., 1993) by cellular morphology, growth at $\mathrm{pH} 7$ and peptidoglycan type: the latter comprises non-motile ovoid cells, grows at $\mathrm{pH} 7$ and has lysine at position 3 in its peptidoglycan. The strains belonging to the genus Alkalibacterium could be distinguished from those of the genus Carnobacterium (Franzmann et al., 1991) by peptidoglycan type and by the production of lactate enantiomer: the genus Carnobacterium has Aly-type peptidoglycan, direct cross-linkage and produces mainly L-lactate from D-glucose.

In the present study, we isolated strains belonging to the same species from two different environments. Although strain $\mathrm{M}^{\mathrm{T}}$ (a laboratory contaminant) exhibited $100 \%$ DNA-DNA similarity with strain 41A obtained from an indigo sample, the optimum growth temperature, the $\mathrm{NaCl}$ concentration range for growth, the growth rate and the fermentation of sugar differed depending on the isolation source. Although we do not know the origin of the contaminant in the case of strain $\mathrm{M}^{\mathrm{T}}$, it is considered that it might have originated from the ubiquitous environments in which indigo fermentation takes place, because no micro-organism was added artificially to the fermentation. However, we do not know the reason why such an obligately alkaliphilic bacterium exists ubiquitously. 
Table 1. Characteristics of Alkalibacterium iburiense and related species

+ , Positive result; -, negative result; W, weak; ND, not determined.

\begin{tabular}{|c|c|c|c|c|}
\hline Characteristic & A. iburiense & A. psychrotolerans & A. olivapovliticus & M. psychrotolerans \\
\hline Motility & + & + & W & + \\
\hline Flagella & Peritrichous & Peritrichous & Polar & Peritrichous \\
\hline Growth $\mathrm{pH}$ range & $9-12$ & $9-12$ & $\geqslant 8,<11 \cdot 0$ & $6 \cdot 0-10 \cdot 0$ \\
\hline Optimum pH & $9 \cdot 5-10 \cdot 5$ & $9 \cdot 5-10 \cdot 5$ & $9 \cdot 0-10 \cdot 2$ & $8 \cdot 0-9 \cdot 5$ \\
\hline Growth $\mathrm{NaCl}$ range (\%) & 0 to $14-16$ & $0-17$ & $0-10$ & 0 to $17 \cdot 0-20 \cdot 5$ \\
\hline Optimum $\mathrm{NaCl}$ concn (\%) & $3-13$ & $2-12$ & $0-10$ & $2 \cdot 0-5 \cdot 0$ \\
\hline Specific growth rate $\mu\left(\mathrm{h}^{-1}\right)$ & $0 \cdot 13-0 \cdot 26$ & $1 \cdot 67$ & $0 \cdot 17-0 \cdot 24$ & $0 \cdot 6$ \\
\hline \multicolumn{5}{|l|}{ Antibiotic sensitivity } \\
\hline Chloramphenicol $(2 \mu \mathrm{g})$ & - & $\mathrm{ND}$ & + & $\mathrm{ND}$ \\
\hline DNA G + C content $(\mathrm{mol} \%)$ & $42 \cdot 6-43 \cdot 2$ & $40 \cdot 6$ & $39 \cdot 7$ & $34 \cdot 6-36 \cdot 2$ \\
\hline
\end{tabular}

On the basis of the above results, the isolate was designated a novel species of the genus Alkalibacterium, for which the name Alkalibacterium iburiense sp. nov. is proposed; the type strain is $\mathrm{M}^{\mathrm{T}}$. A description of the novel species is given below.

\section{Description of Alkalibacterium iburiense sp. nov.}

Alkalibacterium iburiense (i.bu.ri.en'se. N.L. neut. adj. iburiense from Iburi, the place where the micro-organism was isolated).

Cells are Gram-positive, peritrichously flagellated, straight rods $(0 \cdot 5-0.7 \times 1 \cdot 3-2 \cdot 7 \mu \mathrm{m})$ and do not produce spores. The intensity of the motility varies depending on the strain. Strains $\mathrm{M} 3^{\mathrm{T}}$ and $41 \mathrm{C}$ exhibit more distinctive motility than strain 41A. Colonies are $2-2 \cdot 5 \mathrm{~mm}$ in size. Both aerobic and anaerobic growth are observed in equal intensities. Colonies are circular, convex and pale white. Catalase, oxidase and aminopeptidase reactions are negative. Growth temperature range is $5-45$ or $10-45^{\circ} \mathrm{C}$. Optimum growth temperature is $30-37^{\circ} \mathrm{C}$. $\mathrm{NaCl}$ range for growth is $0-16$ or $0-14 \%$. The species grows at $\mathrm{pH} 9-12$ but not at $\mathrm{pH} 7-8$; the optimum $\mathrm{pH}$ is $9 \cdot 5-10.5$ at $27^{\circ} \mathrm{C}$. Grows in $0-16 \%(\mathrm{w} / \mathrm{v}) \mathrm{NaCl}$, with optimum growth at $3-13 \%$ (although the range is wide, the data are reproducible). Grows between 10 and $45^{\circ} \mathrm{C}$, the optimum growth temperature being $30-37^{\circ} \mathrm{C}$. Does not hydrolyse starch or gelatin. Ferments D-glucose, Darabinose, $\mathrm{N}$-acetylglucosamine and glycogen but does not ferment D-galactose, raffinose, melibiose, myo-inositol, D-mannitol, D-sorbitol or arbutin. Fermentation of D-xylose, maltose, D-mannose, sucrose, D-fructose, Lrhamnose and trehalose is variable (all positive for the type strain). DL-Lactate is the major end-product from D-glucose. Culture growth is not inhibited by chloramphenicol $(2 \mu \mathrm{g})$, kanamycin (2 and $10 \mu \mathrm{g})$, miconazole $(2,10$ and $25 \mu \mathrm{g})$, trimethoprim $(1 \cdot 25,10$ and $25 \mu \mathrm{g})$, ketoconazole $(25 \mu \mathrm{g})$ and sulfamethoxazole $(25 \mu \mathrm{g})$ but is inhibited by ampicillin (10 and $25 \mu \mathrm{g})$, penicillin $\mathrm{G}(1,2$ and $10 \mathrm{IU})$ and amoxicillin (10 and $25 \mu \mathrm{g}$ ). No quinones can be detected. The peptidoglycan type is A $4 \beta$, Orn-D-Asp. The major cellular fatty acids are $\mathrm{C}_{16: 0}, \mathrm{C}_{16: 1} 7 c$ and $\mathrm{C}_{18: 1} 9 c$. The DNA G $+\mathrm{C}$ content is $42 \cdot 6-43 \cdot 2 \mathrm{~mol} \%$.

Strain $\mathrm{M}^{\mathrm{T}}$ was isolated from a contaminated culture in alkali broth, and strains $41 \mathrm{~A}$ and $41 \mathrm{C}$ were isolated from a polygonum indigo (Polygonum tinctorium Lour.) fermentation liquor obtained from Date city, Iburi, Hokkaido, Japan. The type strain is $\mathrm{M}^{\mathrm{T}}\left(=\mathrm{JCM} 12662^{\mathrm{T}}=\mathrm{NCIMB} 14024^{\mathrm{T}}\right)$.

\section{References}

Aguirre, M. \& Collins, M. D. (1992). Phylogenetic analysis of Alloiococcus otitis gen. nov., sp. nov., an organism from human middle ear fluid. Int J Syst Bacteriol 42, 79-83.

Aguirre, M., Morrison, D., Cookson, B. D., Gay, F. W. \& Collins, M. D. (1993). Phenotypic and phylogenetic characterization of some Gemella-like organisms from human infections: description of Dolosigranulum pigrum gen. nov., sp. nov. J Appl Bacteriol 75, 608-612.

Duckworth, A. W., Grant, W. D., Jones, B. E. \& van Steenbergen, R. (1996). Phylogenetic diversity of soda lake alkaliphiles. FEMS Microbiol Ecol 19, 181-191.

Ezaki, T., Hashimoto, Y. \& Yabuuchi, E. (1989). Fluorometric deoxyribonucleic acid-deoxyribonucleic acid hybridization 
in microdilution wells as an alternative to membrane filter hybridization in which radioisotopes are used to determine genetic relatedness among bacterial strains. Int J Syst Bacteriol 39, 224-229.

Franzmann, P. D., Hopfl, P., Weiss, N. \& Tindall, B. J. (1991). Psychrotrophic lactic acid-producing bacteria from anoxic waters in Ace Lake, Antarctica; Carnobacterium funditum sp. nov. and Carnobacteium alterfunditium sp. nov. Arch Microbiol 156, 255-262.

Horikoshi, K. (1991). Microorganisms in Alkaline Environments. Tokyo/Weinheim: Kodansha/VCH.

Hugh, R. \& Leifson, E. (1953). The taxonomic significance of fermentative versus oxidative metabolism of carbohydrates by various Gram-negative bacteria. J Bacteriol 66, 24-26.

Ishikawa, M., Nakajima, K., Yanagi, M., Yamamoto, Y. \& Yamasato, K. (2003). Marinilactibacillus psychrotolerans gen. nov., sp. nov., a halophilic and alkaliphilic marine lactic acid bacterium isolated from marine organisms in temperate and subtropical areas of Japan. Int J Syst Evol Microbiol 53, 711-720.

Kimura, M. (1980). A simple method for estimating evolutionary rates of base substitutions through comparative studies of nucleotide sequences. J Mol Evol 16, 111-120.

Krulwich, T. A. \& Guffanti, A. A. (1989). Alkalophilic bacteria. Annu Rev Microbiol 43, 435-463.

Krulwich, T. A., Ito, M. \& Guffanti, A. A. (2001). The $\mathrm{Na}^{+}$-dependence of alkaliphily in Bacillus. Biochim Biophys Acta 1505, 158-168.

Marmur, J. (1961). A procedure for the isolation of deoxyribonucleic acid from micro-organisms. J Mol Biol 3, 208-218.

Nielsen, P., Fritze, D. \& Priest, F. G. (1995). Phenetic diversity of alkaliphilic Bacillus strains: proposal for nine new species. Microbiology 141, 1745-1761.

Ntougias, S. \& Russell, N. J. (2001). Alkalibacterium olivoapovliticus gen. nov., sp. nov., a new obligately alkaliphilic bacterium isolated from edible-olive wash waters. Int J Syst Evol Microbiol 51, 11611170 .

Okada, S., Uchimura, T. \& Kozaki, M. (1992). Laboratory Manual for Lactic Acid Bacteria. Tokyo: Asakura-shoten (in Japanese).

Padden, A. N., Dillon, V. M., Edmonds, J., Collins, M. D., Alvarez, N. \& John, P. (1999). An indigo-reducing moderate thermophile from a woad vat, Clostridium isatidis sp. nov. Int J Syst Bacteriol 49, 1025-1031.
Saitou, N. \& Nei, M. (1987). The neighbor-joining method: a new method for reconstructing phylogenetic trees. Mol Biol Evol 4, 406-425.

Takahara, Y. \& Tanabe, O. (1960). Studies on the reduction of indigo in industrial fermentation vat (VII). J Ferment Technol 38, 329-331.

Takami, H., Inoue, A., Fuji, F. \& Horikoshi, K. (1997). Microbial flora in the deepest sea mud of the Mariana Trench. FEMS Microbiol Lett 152, 279-285.

Tamaoka, J. \& Komagata, K. (1984). Determination of DNA base composition by reversed-phase high-performance liquid chromatography. FEMS Microbiol Lett 25, 125-128.

Thompson, J. D., Higgins, D. G. \& Gibson, T. J. (1994). CLUSTAL W: improving the sensitivity of progressive multiple sequence alignment through sequence weighting, position-specific gap penalties and weight matrix choice. Nucleic Acids Res 22, 4673-4680.

Thongaram, T., Kosono, S., Ohkuma, M., Hongoh, Y., Kitada, M., Yoshinaka, T., Trakulnaleamsai, S., Noparatnaraporn, N. \& Kudo, T. (2003). Gut of higher termites as a niche for alkaliphiles as shown by culture-based and culture-independent studies. Microbes Environ 18, 152-159.

Yumoto, I. (2002). Bioenergetics of alkaliphilic Bacillus spp. J Biosci Bioeng 93, 342-353.

Yumoto, I. (2003). Electron transport system in alkaliphilic Bacillus spp. Recent Res Dev Bacteriol 1, 131-149.

Yumoto, I., Yamazaki, K., Sawabe, T., Nakano, K., Kawasaki, K., Ezura, Y. \& Shinano, H. (1998). Bacillus horti sp. nov., a new Gramnegative alkaliphilic bacillus. Int J Syst Bacteriol 48, 565-571.

Yumoto, I., Yamazaki, K., Hishinuma, M., Nodasaka, Y., Suemori, A., Nakajima, K., Inoue, N. \& Kawasaki, K. (2001). Pseudomonas alcaliphila sp. nov., a novel facultatively psychrophilic alkaliphile isolated from seawater. Int J Syst Evol Microbiol 51, 349-355.

Yumoto, I., Nakamura, A., Iwata, H., Kojima, K., Kusumoto, K., Nodasaka, Y. \& Matsuyama, H. (2002). Dietzia psychralcaliphila sp. nov., a novel, facultatively psychrophilic alkaliphile that grows on hydrocarbons. Int J Syst Evol Microbiol 52, 85-90.

Yumoto, I., Hirota, K., Nodasak, Y., Yokota, Y., Hoshino, T. \& Nakajima, K. (2004). Alkalibacterium psychrotolerans sp. nov., a psychrotolerant obligate alkaliphile that reduces an indigo dye. Int J Syst Evol Microbiol 54, 2379-2383. 